\title{
Reinhold Schwarz német nőgyógyászprofesszor emlékezete (1929-2017)
}

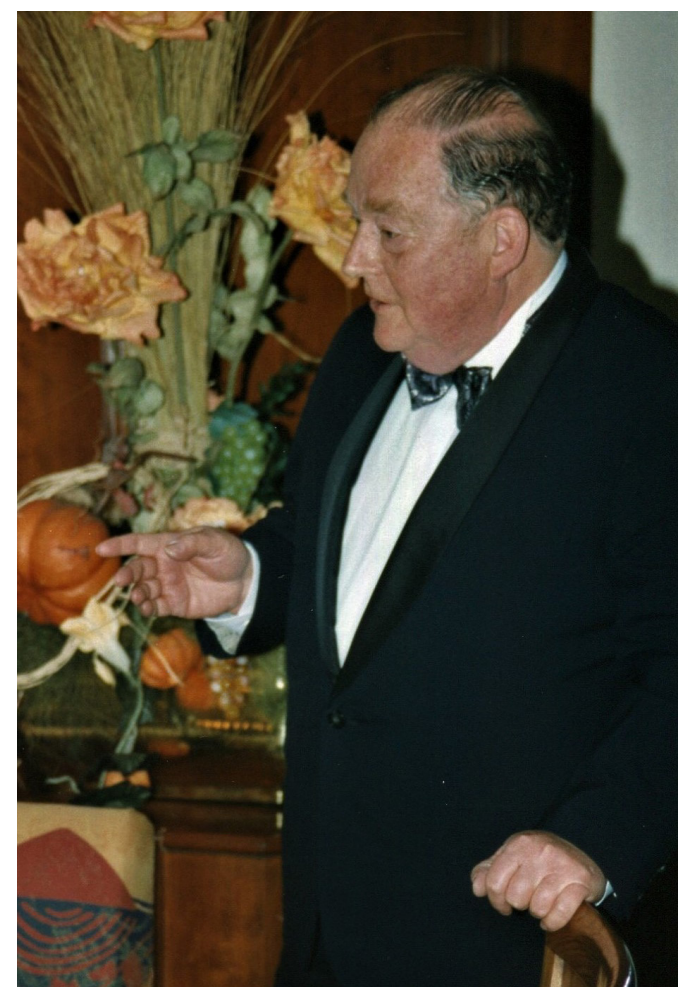

1. ábra

| Schwarz professzor 75. születésnapján (2004)

Reinhold Schwarz 1929. július 25-én született Stuttgartban, majd 7 éves korában a család Lipcsébe költözött. Mint elmondta, az átállás - a nyelvi eltérések (sváb dialektus Stuttgartban, szász dialektus Lipcsében) és az emberi mentalitásbeli különbségek miatt - nehéz volt. Itt végezte tanulmányait, 1948-ban érettségizett. Ezt követően elvégezte a Lipcsei Egyetem orvosi fakultását, majd 1953-tól két évig a kötelező segédorvosi gyakorlati idejét („Pflichtassistentzeit”) Klettwitzben, a „bányászkórház" sebészeti osztályán töltötte.

1955-tôl a Lipcsei Egyetem Szülészeti és Nőgyógyászati Klinikáján tanársegéd, majd 1958-ban Helmut Kyank professzorral együtt Rostockba, az egyetem Szülészeti és Nőgyógyászati Klinikájára került; 1959-ben itt lett nőgyógyász szakorvos, majd 1963-ban habilitált, és 1964-től a Rostocki Egyetem Szülészeti és Nőgyógyászati Klinikáján volt egyetemi magántanár, igazgatóhelyettes. Ahogy elmondta, radiológus szakorvosi minősítést azért szerzett, mert a radiológiához is értenie kellett. 1974-ben kinevezték egyetemi tanárnak, annak ellenére, hogy nem volt az SED* tagja, sőt hívő keresztény lévén, egyházi kórusban énekelt.

1978 és 1981 között Irakban, a Basrai Egyetemen volt „vendégprofesszor”. 1983-ban megválasztották a Német Tudományos Akadémia (Leopoldina) tagjává; 1988 és 1993 között a Society of European Gynecologic Oncology aktív tagja volt.

A fordulat évében, 1989-ben a keletnémet Szülészeti és Nőgyógyászati Társaság első szabadon választott elnöke lett. Ő kezdeményezte Martin Link (Drezda), Hans-Joachim Seewald (Jena) és Wolfgang Weise (Magdeburg) professzorokkal együtt a volt Német Demokratikus Köztársaság (NDK) területén a Szülészeti és Nőgyógyászati Társaság új struktúrájának felépítését. Ugyanígy részt vett az Észak-német Szülész és Nőgyógyász Társaság szervezésében, amely a Német Szülészeti és Nőgyógyászati Társaság lokális szervezete. Szervezőmunkája elismeréseként 1999-ben e Társaság tiszteletbeli tagjává választották. 1982 és 1995 között a Zentralblatt für Gynäkologie und Geburtshilfe föszerkesztóje volt. 2002-ben lett az Osztrák Szülészeti és Nőgyógyászati Társaság tiszteletbeli tagja.

Az NDK felbomlása utáni években, 1993 és 1997 között a Rostocki Egyetem Szülészeti és Nőgyógyászati Klinikájának igazgatója, három évig a Rostocki Egyetem Orvoskarának igazgatóhelyettese. A rendelkezésére jutott 4 év alatt korszerúsítette a klinikát, új mútôt építtetett, elődje programpontjait folytatva, hathatósan támogatta az emlősebészetet és az asszisztált reprodukciós programot. A radiológiai részlegben bevezette a rutinszerü mammográfiás szűrést.

Kyank, Wilkens, Schwarz professzoroknak és az őket követő Friese professzornak köszönhető, hogy a Rostocki Egyetem Szülészeti és Nógyógyászati Klinikája a keleti-tengeri térség vezető klinikája lett; a Nemzetközi Emlőcentrum címet 2006-ban kapta meg.

Schwarz professzor tudományos munkásságának fóbb pontjai: a nőgyógyászati onkológia és sugárterápia, a szív- és a keringési rendszer élettana és kórélettana a terhességben, a patológiás terhesség klinikopatológiája. Számos doktori disszertációnak volt a kezdeményezője. Több könyvet írt vagy szerkesztett a szülészet és nőgyógyászat tárgyköréből:

- Kyank, Helmut. Lehrbuch der Geburtshilfe. Thieme, VEB, Leipzig, 1971. 
- Kyank, Helmut. Lehrbuch der Geburtshilfe. Thieme, VEB, Leipzig, 1976, 2., veränd. Aufl.

- Schwarz, Reinhold. Gynäkologie und Geburtshilfe. Verlag Volk u. Gesundheit, VEB, Berlin, 1977, 1. Aufl.

- Schwarz, Reinhold. Gynäkologie und Geburtshilfe. Verlag Volk u. Gesundheit, VEB, Berlin, 1979, 2., überarb. Aufl.

- Schwarz, Reinhold. Gynäkologie und Geburtshilfe. Verlag Volk u. Gesundheit, Berlin, 1985, 3., überarb. Aufl.

- Kyank, Helmut. Gynäkologische Operationen. Barth, Leipzig, 1986.

- Kyank, Helmut. Gynäkologische Operationen. Barth, Leipzig, 1987, 2., durchges. Aufl.

- Schwarz, Reinhold. Gynäkologie und Geburtshilfe. Verl. Volk u. Gesundheit, Berlin, 1988, 4., unveränd. Aufl.

- Schwarz, Reinhold. Gynäkologie und Geburtshilfe. Verl. Volk u. Gesundheit, Berlin, 1989, 5. Aufl.

- Scholz, Horst. Prä- und perinatale Infektionen. Fischer, Jena, 1991, 1. Aufl.

1997-ben meghívott a Nőgyógyászati Patológiai Laboratórium vezetőjének: mindenben szabad kezet adott. A kitűnő, nagy formátumú metszetmúzeumot is szívügyének tekintette. Rengeteg jó tanáccsal látott el, a kisujjában volt a nógyógyászati patológia. 2004 decemberéig a klinikán külön szobája volt, ahol az aktuális esetekről hetenként beszámoltam neki. Hatalmas tudásanyaggal rendelkezett, és ezt továbbadta.

Mint a Rostocki Egyetem legendás hírü oktatója, nagyszerű klinikopatológiai előadásokat tartott. Erről két esetben magam is meggyőződhettem. Sokat rajzolt, miközben a tanulságos eseteket ismertette, s nem hallgatta el a diagnosztikai nehézségeket sem. A betegekhez közvetlen kapcsolata volt, a mütétek közepette is nyugalmat sugárzott, de a kockázatos mútéti megoldásokat elvetette. 2007-ig naprakész ismeretekkel rendelkezett.

Többször voltam náluk vendég, jó humorú és minden után érdeklődő egyéniség volt, Semmelweis tanainak rendíthetetlen híve. Mint hobbiszakács és „bármixer” utolérhetetlen volt. Bejárta az osztrák és a svájci Alpokat, szívesen emlékezett prágai és budapesti tartózkodásaira. Magyar barátai közül a legtöbbször Papp Zoltán profeszszort emlegette, akivel tudomásom szerint hosszú éveken át soha nem maradt el az év végi, karácsonyi lapon küldött kölcsönös jókívánság.

2007-ben elhagyta Rostockot, és Lipcsében telepedett le. Itt egyik szószólója volt az 1968. május 30-án felrobbantott lipcsei egyetemi templom jelképes helyreállításának (itt alapították 1419-ben a Lipcsei Egyetemet, itt prédikált dr. Martin Luther, itt is orgonált Johann Sebastian Bach).

Ha 2008 és 2016 között valahányszor a lipcsei vagy a hallei egyetemen elöadásom volt, kijött elém a lipcsei állomásra, majd együtt ebédeltünk valahol a városban, és hosszasan beszélgettünk. Az utolsó években járási problémákkal küszködött. 2017. december 1-jén hunyt el Lipcsében. A nagyszerű klinikusról és emberről Michael Bolz és Bernd Gerber írt méltó megemlékezést.

\section{Jegyzetek}

SED: a Sozialistische Einheitspartei Deutschlands 1946-ban alakult meg Németország szovjet megszállási övezetében, amely az 1949-ben létrejött NDK állampártja, politikai vezető ereje volt 1990-ig.

\section{Felhasznált irodalom}

https://de.wikipedia.org/wiki/Reinhold_Schwarz_(Gynäkologe) Biografie Schwarz, Reinhold im Catalogus Professorum Rostochiensium

Tabellarischer Lebenslauf aus der Personalakte der Universität Rostock Verzeichnis der wissenschaftlichen Arbeiten aus der Personalakte der Universität Rostock

Link M. Im zwölften Jahr der deutschen Einheit. In: 50 Jahre Berufs verband der Frauenärzte. Frauenarzt 1992; 43: 194-196.

Bolz M, Gerber B. Professor Reinhold Schwarz zum 80. Geburtstag. Ärzteblatt Mecklenburg-Vorpommern 2009; 7: 271.

Bolz M, Gerber B. Nachruf für Professor Dr. med. Reinhold Schwarz. Ärzteblatt Mecklenburg-Vorpommern 2018; 28: S70-S71.

Makovitzky József $d r$.

\author{
"Absque pugna non est victoria." \\ (Küzdelem nélkül nincs győzelem.)
}

